Вілкул Ю. Г., д.т.н., професор (Академія гірничих наук України, президент Академії, м. Кривий Ріг), Скачков А. А., гірничий інженер (Північний гірничо-збагачувальний комбінат, генеральний директор, м. Кривий Ріг), Жуков С. О., д.т.н., професор (ЗВО «Криворізький національний університет», м. Кривий Ріг)

\title{
ОРГАНІЗАЦІЙНО-ТЕХНОЛОГІЧНІ ПРІОРИТЕТИ ВИРІШЕННЯ ЕКОЛОГІЧНИХ І ПРОМИСЛОВИХ ПРОБЛЕМ КРИВБАСУ
}

Мета дослідження - визначити сучасний стан та тенденції в гірничій галузі України; екологічні умови Кривбасу та технологічні можливості зменшення сейсмічних наслідків масових вибухів у кар'єрах. Методи дослідження полягають в техніко-економічному аналізі гірничовидобувної промисловості України, і в теоретичному обґрунтуванні технологічних рішень, що зменшують негативний вплив відкритих розробок на навколишнє середовище.

Досліджено стан та еволюційні тенденції гірничовидобувної промисловості України за останні десять років, а також вплив гірничовидобувних підприємств на довкілля Кривбасу. Визначено, що найбільш екологічно агресивним фактором серед технологічних процесів є вибухове руйнування гірських порід. Аналіз розробки кар'єрів № 3 «АрселорМіттал Кривий Ріг» та «ПівдГЗК» свідчить про їх просторове сполучення у найближчі роки. Безпосередня ліквідація скельного ціліка між кар'єрами ускладнюється, як просторово, так і технологічно, особливо через сейсмічні обмеження, але розроблені авторами рішення та заходи максимально спрощують й убезпечують цю стадію.

Висновки. Адаптація авторського аналітичного обґрунтування технології руйнування гірських порід до специфічних умов ліквідації гірського масиву, який розділяє сусідні кар'єри, є реально перспективною.

Наукова новизна дослідження полягає у розгляді суміжних кар'єрів як єдиної складної динамічної системи. Крім того, - в адаптації авторського аналітичного обґрунтування технології вибухового руйнування порід до конкретних умов ліквідації масиву, що розділяє сусідні кар'єри. 
Практичне значення полягає в тому, що результати досліджень визначаються високим рівнем придатності для їх використання при проектуванні гірничих робіт кар'єрів «АрселорМіттал Кривий Ріг» і «ПівдГЗК».

Ключові слова: гірнича промисловість, відкрита розробка, вибухове руйнування.

Проблема та її зв'язок з практичними завданнями. В даний час Україна переживає тотальну кризу, яка все глибше проникає в усі структури країни, зв'язки між ними і життя суспільства. Погіршуються всі економічні, соціальні та демографічні показники. I все це відбувається за умов наявності в Україні колосальних земельних і водних ресурсів, логістичного потенціалу, унікальних за цінністю, обсягами запасів і різноманіттям сировини родовищ корисних копалин [1].

Головною проблемою такої парадоксальності є насамперед застарілість і загрожуюча невідповідність не тільки гірничих технологій, але й самої стратегії та доктрини надрокористування. Тому ніяк не можна ігнорувати необхідність й актуальність повномасштабних наукових досліджень, особливо таких, що стосуються вдосконалення видобувних технологій та охорони довкілля, яке найбільшою мірою потерпає від гірничо-видобувних робіт. А відтак, головною домінантою завдань гірничої науки на даному етапі $€$ максимально можливе узгодження потреб і можливостей в сфері експлуатації надр і актуалізація відповідних сучасним вимогам технологій і менеджменту [2].

Потребують модернізації усі процеси відкритих гірничих робіт, але в даному контексті проаналізувати їх разом - просто неможливо, тому нижче автори обмежуються перспективним на їх переконання рішенням щодо найвитратнішого процесу - підготовки порід до виймання. Проблема тут конкретизується відсутністю адекватного обґрунтування інженерних рішень щодо нових, безпрецедентних ситуацій, одним з прикладів чого $є$ потреба в ліквідації рудного цілика між кар'єрами двох ГЗК, що й розглянуто нижче.

Аналіз останніх досліджень і публікацій. Останні роки ринок залізної руди стабільно перебуває в депресивному стані. Ціни на залізорудну сировину досягли мінімальних показників за останні 10 років. Зниження цін відбувається на тлі зростання надлишку сировини на світовому ринку. Підприємства гірничо-металургійного комплексу (ГМК) опинилися в критичній ситуації. А так, як наукова діяльність багато в чому залежить від їх роботи, то зрозуміло, чому ви- 
конання науково-дослідних робіт до 2014-2015 років скоротилося на гірничо-збагачувальних комбінатах (ГЗК) Кривбасу майже на 70\%, а з 2016 року - його практично призупинено [1-2].

Гірничо-металургійні підприємства України протягом 2016-2017 років скоротили виручку від експорту залізорудної сировини в 1,9 рази, і вона склала лише близько \$ 100 млн внаслідок падіння світових цін.

Основними покупцями залізорудної сировини стали: Китай 42,8\% виручки, Австрія - 12,2\%, Японія - 10,5\%. Виробництво сталі в 2015 р склало лише 23 млн т., що - на 29\% менше аналогічного показника в далеко не найкращому для галузі 2013 році. Не набагато кращими є показники і в 2017-2018 рр. Експортні ціни на основну продукцію вітчизняної металургії знизилися в середньому на $40 \%$ i досягли мінімальних значень за останні 15 років. Галузь опинилася на межі виживання і несе багатомільярдні збитки. Максимальну ціну на залізну руду було зафіксовано в 2011 р. на рівні 191,7 \$/т, мінімальну - в 1988 р - 10,51 \$/т. Піки останніх чотирьох циклів відстають один від одного приблизно на 30 років. Кожен з них складався 3 10-річного підйому, за яким слідував обвальний спад тривалістю близько п'яти років, що переходив у порівняно плавне зниження, яке тривало ще 15 років. Піки - зареєстровано в 1917, 1951, 1980 і 2011 рр. Найнижчі точки припали на 1931, 1971, 2002 рр. Якщо поточний цикл буде повторювати попередні, то наступний мінімальний цикл або точка повороту прийдеться на 2030 р.

Усі інвестиційні складові ВВП України скоротилися до історичного мінімуму в 12\%. За оцінками міжнародних експертних організацій, за рівнем інвестиційної активності Україна вийшла на рівень найбідніших країн світу: Барбадос, Буркіна-Фасо, Південний Судан. Вона визнана найбіднішою країною Європи за доходами на душу населення, випередивши Молдову і Албанію. За рівнем середньої зарплати перебуває на рівні таких відсталих африканських держав, як Габон і Сенегал. Спад у будівництві, машино- та суднобудуванні призвів до того, що внутрішнє споживання сталевого прокату в Україні впало до мінімуму в 3,12 млн т. Споживання металу на душу населення становить менше 90 кг, що є більше, ніж в три рази нижчим показників Росії та Польщі - 300 і 314 кг відповідно. В кінці 80 рр. цей показник становив 1,06 т на людину і був вищим, ніж у США, Канаді, Німеччині, Росії, Японії, Франції, Англії, Бразилії, Австралії та інших розвинених країнах. Такої кризи, як сьогодні, в історії українського ГМК ще не було. 
Зараз головне завдання наукового супроводу підприємств ГМК - стабілізувати виробництво. Якщо ми в кінці року будемо мати той же ГМК, що і на початку - це вже буде великим успіхом. Йде боротьба за кожну гривню в собівартості продукції, за кожне робоче місце, і реально досягти прогресу за браком часу й відсутності значних інвестицій можливим $\epsilon$ виключно за рахунок максимальної модернізації існуючих технологічних комплексів.

Щодо БПР, то аналіз теорії вибухового руйнування кристалічних середовищ і виробничої статистики [3; 4] свідчить про те, що одним $з$ найменш досліджених теоретично і невирішених практично питань $€$ нерівномірне формування під дією вибуху напруженодеформованого стану крайових зон бортів кар'єрів, оптимізувати що стає можливим шляхом диференційованого енергонасичення породного масиву, удосконалення механізму взаємодії свердловинних зарядів ВР та технології БВР у цілому, зокрема - способів створення реально працюючих додаткових відбиваючих пружні хвилі екрануючих щілин та конструкцій зарядів для цього [5; 6]. У зв'язку з чим авторами опрацьовувалася ідея застосування вертикальних укосів уступів, висотою до 10 м, та поглиблення диференційованого енергонасичення масиву вибухом за рахунок спеціально розроблених різнотипних зарядів ВР, для вирішення чого задачі досліджень формулювалися згідно з нею, а саме: заряди першого ряду свердловин (основні заряди рихлення) ініціюються тільки після проходження скрізь них прямої та відбитої укосом уступу хвиль вибуху зарядів другого ряду (заряди попереднього знеміцнення породи й утворення відбиваючої щілини), створюючи завдяки цьому умови для симетричної дії основних зарядів між двома відбиваючими поверхнями - вертикального укосу уступу з одного, та відбиваючої щілини - з іншого.

Викладення матеріалу досліджень. Як відмічалося, Україна $€$ унікально багатим регіоном щодо покладів мінеральних копалин. При площі республіки приблизно 0,03\% від площі земної поверхні, в країні видобувається близько 5\% світового обсягу мінеральних ресурсів. Вона входить у першу десятку країн - постачальників мінеральної сировини. Саме в Україні - всесвітньо відомі родовища марганцю і $80 \%$ його світового виробництва, $14 \%$ залізної руди, $7 \%$ кам'яного вугілля. Ми виробляли всього лише кілька років тому майже $90 \%$ титану, більше половини ртуті, графіту, 90\% самородної сірки, 70\% облицювального каменю та ін. Запасів у нас - достатньо. А головний висновок щодо раціонального використання надр країни свідчить, що Кривбас і зараз, як і раніше, залишається основною базою залі- 
зорудної промисловості України і головними тут є комплексна розробка родовищ і екологія.

Реально ж надра Криворізького басейну використовуються украй нераціонально. Незважаючи на те, що у видобутій гірничій масі міститься багато видів мінеральної сировини, використовується тільки один - залізна руда. Решта відправляються у відходи і складуються у відвалах і хвостосховищах, утворюючи нові - техногенні родовища.

В результаті гірничих робіт у Кривбасі порушено понад 34 тис. га землі. 3585 км² території майже на 40 км² розташовані кар'єри і зони обвалення, на 70 км² - хвостосховища з понад 3 млрд т. відходів. Понад 70 км² - під відвалами порожніх порід, яких тут накопичено понад 9 млрд т. Тільки для п'яти ГЗК Кривбасу загальна площа земельного відводу перевищує 34 тис. га. Висота відвалів вже понад 120 м, дамб хвостосховищ - 90 м. В результаті діяльності ГМК в атмосферу викидається понад 600 тис. т. пилу та понад 1 млн м³ шкідливих і високотоксичних газів. Це призводить до того, що в багатьох районах міста концентрація пилу і шкідливих речовин набагато перевищує гранично допустимі норми. До цього додається ще й проблема вироблених підземними гірничими роботами не врахованих значних за об'ємами порожнин.

У зв'язку з цим діяльність науковців-гірників, яку координує Академія гірничих наук (АГН), передбачає, перш за все, розробку екологічно чистих технологій видобутку руд на глибоких кар'єрах Кривбасу. Щорічно Академія бере участь у реалізації Довгострокової програми з вирішення екологічних проблем Кривбасу та поліпшення стану навколишнього природного середовища на 2011-2022 роки. Стає вкрай актуальною програма «Розробка техніки і технології рекультивації порушених гірничими підприємствами земель».

У 1993 році на ЦГЗК було зроблено спробу збагачення окислених руд з використанням випалювальних машин продуктивністю 3 млн т концентрату в рік. Однак цей спосіб виявився дуже витратним і екологічно шкідливим. В даний час вченими АГНУ розроблено нову технологію збагачення окислених кварцитів високоградієнтними магнітними сепараторами, матеріальною базою для якої стануть кар'єри Південного ГЗК і «Арселор Міттал Кривий Ріг», де запаси руд оцінюються в 2 млрд т з вмістом заліза 36,5\%. Вже чотири роки академія бере участь у розробці й упровадженні цільової регіональної програми «Перехід гірничовидобувних підприємств, підконтрольних Криворізькому гірничопромисловому територіальному управлінню 
Держгірпромнагляду України, на безтротилові екологічно безпечні вибухові речовини». У 2015 р. цій програмі Академією спільно з ПівнГЗК, ІнГЗК, ЦГЗК, КЗРК виконано науково-дослідних робіт на суму понад 3,5 млн грн. Щорічно АГНУ бере активну участь в підготовці та проведенні Міжнародної конференції «Сталий розвиток Кривбасу», яка проходить в Криворізькому національному університеті. Академія проводить симпозіуми з управління якістю мінеральної сировини. Президія АГНУ вживає заходів щодо посилення і зміцнення науково-виробничих комплексів, відділень і центрів провідними вченими та керівниками підприємств. Міжнародна діяльність АГНУ відкрила можливість залучати до нашої діяльності іноземних вчених 3 США, Китаю, Польщі, Румунії, Італії та інших країн. Значна увага приділяється підготовці кадрів вищої кваліфікації. Більшість академіків і членкорів АГНУ працюють у сфері вищої гірничої освіти. Це дає їм можливість довести досягнення гірничої науки до широкої аудиторії при підготовці фахівців для гірничої промисловості.

Продовжуючи свою діяльність, АГНУ планує зосередити найближчим часом НДКР в таких основних напрямках: гідрогенізація бурого і кам'яного вугілля; підвищення продуктивності нафтових і газових свердловин; збагачення слабомагнітних руд; комбінована відкрито-підземна розробка родовищ корисних копалин; застосування емульсійних вибухових речовин при виконанні буро-підривних робіт (БПР).

При цьому саме БПР приділяється особлива увага, так як вони $є$ найбільш екологічно агресивними з усіх інших техногенних чинників відкритих розробок. Стосовно цього варто розглянути ефективність нового метода БПР, вельми ефективного щодо екологічного впливу на довкілля, надійно апробованого протягом кількох років упровадження в умовах кар'єру «Північний» ПАТ ГЗК «Укрмеханобр», а тому рекомендованого для застосування за виключно складних умов ліквідації рудного масиву між двома кар'єрами різних ГЗК, де технологія гірничих робіт і механізація виробничих процесів передбачала наступне [7].

При ліквідації міжкар'єрної перемички вимагалося збереження існуючої технології та механізації виробничих процесів з відповідними змінами, зумовленими реконструкцією гірничотранспортної схеми в кар'єрі з заміною морально застарілого і фізично зношеного устаткування і придбанням нового для збільшення продуктивності кар'єpy.

Рудниим покладом є потужний крутопадаючий пласт, розбитий 
декількома скидами і здвигами. Вміщуючими породами є некондиційні кварцити, кристалічні сланці й інші скельні породи. Рудний поклад в межах кар'єрного поля покритий осадовими породами потужністю в межах невідпрацьованих ділянок 19-54 м, складаючи в середньому 34 м.

Як навантажувальні механізми передбачається використовувати:

- на видобутку кварцитів та виїмці розкривних порід - екскаватори ЭКГ-8И, ЭКГ-10, Terex RH-170, навантажувачі CAT 992G;

- на перевантажувальних площадках - ЭКГ-8И, ЭКГ-10;

- на відвалах скельного розкриву і складуванні окислених кварцитів - екскаватори ЭШ 6/45, ЭКГ-6,3, ЭКГ-8И.

Руда і скельне розкриття родовища відносяться до міцних порід і вимагають попереднього розпушування вибуховим способом. Дроблення скельних порід міцністю $f=4-18$ передбачається методом свердловинних зарядів. Буріння вибухових свердловин передбачається верстатами шарошкового буріння СБШ-250MH i Atlas Copco Pit Viper 275. Як вибухову речовину (BP) передбачено застосовувати Анемікс. Для ініціювання свердловинних зарядів застосовується система типу «Нонель».

Для зниження інтенсивності сейсмічного впливу вибухові роботи передбачається проводити із застосуванням багаторядного уповільненого підривання, а комутацію вибухової мережі - за секційною схемою. Для уповільненого підривання застосовуються піротехнічні реле РП-92 з номінальними уповільненнями 20, 35 мс.

Вибухонебезпечна зона по розлітанню осколків для людей приймається 500 м при застосуванні Анеміксу Р-70.

Для формування укосів скельних уступів при оформленні постійних бортів передбачено контурне підривання похилих свердловин, для буріння яких застосовується верстат ROC-L8 фірми Atlas Сорсо.

Враховуючи усі акцентовані вище особливості міжкар'єрної зони, а також те, що практично всю передбачену робочим проектом «Південгіпроруди» виробничу програму порушено, за умов, коли нинішнє становище кар'єру № 3 вимагає негайного вирішення зазначеної проблеми і не допускає різкого зниження продуктивності по руді, автори пропонують застосувати розроблену ними технологію вибухового руйнування порід з диференційованим енергонасиченням масиву [8], адаптація якої до розглянутих умов максимально відповідає їм і вимагає мінімальних доробок, враховуючи аналогіч- 
ність умов та вимог щодо застосування, як операційну, так і ресурсну (типи вибухових матеріалів, засобів підривання тощо).

Реалізується технологія з урахуванням рекомендації зв'язати масив перед вибухаючим зарядом від розпадання, але виконується це не підпірною стінкою, а за рахунок першочергового підривання зарядів у другому від укосу ряді свердловин. Підриванням цього ж ряду забезпечується створення відбиваючої щілини, симетричної укосу уступу. Перший ряд підривається через уповільнення, тривалість якого забезпечує поступальне і зворотне проходження прямої і відбитої хвиль першого вибуху через масив, обмежений другим рядом і укосом (рис. 1).

Щоб унеможливити пришвидшене тріщиноутворення у напрямі покрівлі уступу, зменшено масу заряду у другому ряді на $30 \div 50 \%$, збільшивши довжину забивочного матеріалу. А для утворення відбиваючої щілини в площині свердловин цього ж ряду використовуються спеціально розроблені комбіновані лінійні заряди спрямованої дiï.

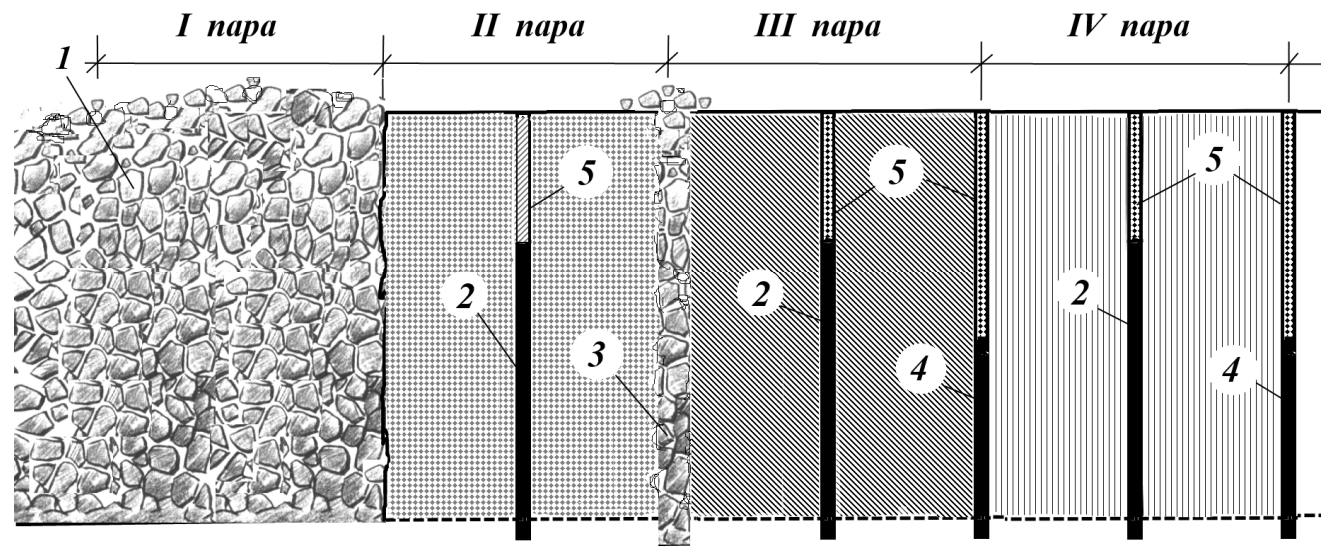

Рис. 1. Схема способу диференційованого енергонасичення породного масиву зі зворотнім підриванням симетрично працюючих свердловинних зарядів в уступах з вертикальними укосами:

1 - підірвана гірнича маса; 2 - заряд рихлення повної маси; 3 - відбиваюча щілина; 4 - комбінований заряд неповної маси для утворення відбиваючої щілини і попереднього знеміцнення породи

Першими ініціюють одночасно високобризантні заряди ВР, які утворюють лінійні концентратори напружень на стінках свердловини і в свою чергу підривають основний заряд з низькобризантною ВР.

У разі підривання міжкар'єрного масиву особливого значення набуває сейсмічний прояв масових вибухів, так як його впливу під- 
даються об'єкти обох комбінатів. Але на даний час не існує універсальних теоретичних методів прогнозу сейсмічної небезпеки вибухів на кар'єрах і захисту споруд. Тому основними методами оцінки сейсмічного впливу вибуху є експериментальні вимірювання й обробка та аналіз їх результатів з використанням різних засобів ініціювання вибуху у відповідності з [9], забезпечення чого і досліджувалося авторами.

Основними факторами, які характеризують сейсмічний вплив масових вибухів в кар'єрі були прийняті: маса ВР на ступінь уповільнення у вибухових блоках - Q; відстань від блока до точки спостереження - $R$. Основним параметром, що характеризує інтенсивність, запропоновано вважати модуль вектора максимальної швидкості коливань (зміщення) ґрунту в основі споруд. Експериментально доведено, що цей параметр при миттєвому вибуху краще, ніж амплітуда зміщення, прискорення та період коливань корелює з масою ВР і відстанню до точки спостереження. Для визначення пропорційності між рівнем сейсмічних коливань ґрунту в заданій точці та масою ВР при масових вибухах на кар'єрах рекомендовано співвідношення $Q=U^{2} R^{3} K^{-2}$, де $U$ - максимально допустима швидкість сейсмічних коливань ґрунту біля охоронного об'єкту, см/с; $K_{\phi}-$ коефіцієнт сейсмічності для даного району. При підрахунку граничного значення маси $\mathrm{BP} K_{\phi}$ визначається експериментально під час моніторингу сейсмічної безпеки масових вибухів, максимально допустима швидкість сейсмічних коливань - за методикою [10].

Починаючи з 2006 року і по теперішній час було здійснено понад 70 експериментальних вимірів рівня сейсмічних хвиль при проведенні вибухів на кар'єрах Кривбасу за умов використання для ініціювання вибуху ДШ та неелектричних систем «Прима-Ера» і «Нонель». Аналіз результатів експериментів дозволяє стверджувати:

- рівень сейсмічних хвиль при проведенні вибухів жодного разу не перевищив нормативного рівня;

- система ініціювання вибуху суттєво впливає на сейсмічність масових вибухів - при застосуванні систем «Прима-Ера», «Нонель», сейсмічна дія вибуху практично на $30 \% €$ меншою, ніж у випадку застосування ДШ;

- на сейсмічність вибуху впливає не сама по собі система ініціювання, а максимальна маса ВР, яка приходиться на ступінь уповільнення при застосуванні тієї чи іншої системи ініціювання: при застосуванні ДШ - 810 кг, а систем «Нонель», «Прима-ЕРА» - 331 кг.

На основі даних моніторингу протягом 2007-2017 років, за умо- 
ви використання системи ініціювання «Прима-Ера», було отримано експериментальне значення коефіцієнту сейсмічності $K_{\phi}=138 \pm 11$; у випадку ж застосування ДШ $-K_{\phi}=110 \pm 12$. Отримане значення $K_{\phi}$ відповідно до описаної вище методики дає змогу встановити залежність між граничним значенням кількості ВР та рівнем сейсмічних коливань, які можуть виникнути внаслідок одночасного ініціювання відповідної маси ВР. Результати розрахунків сейсмобезпечної маси ВР за умови використання ДШ наведено на рис. 2, а для неелектричних систем «Прима-Ера» та «Нонель»- на рис. 3.

Отримані графіки пропонуються для практичного використання при проектуванні масових вибухів у кар'єрі № 3 «АрселорМіттал Кривий Ріг».

Методика їх використання дозволяє оперативно оцінити сейсмобезпечні параметри підривання, які забезпечують збереження стійкості бортів, укосів уступів, споруд при заданій допустимій швидкості коливань іє важливою умовою вдосконалення БПР й упровадження розробленої технології для ліквідації розглянутого масиву між кар'єрами.

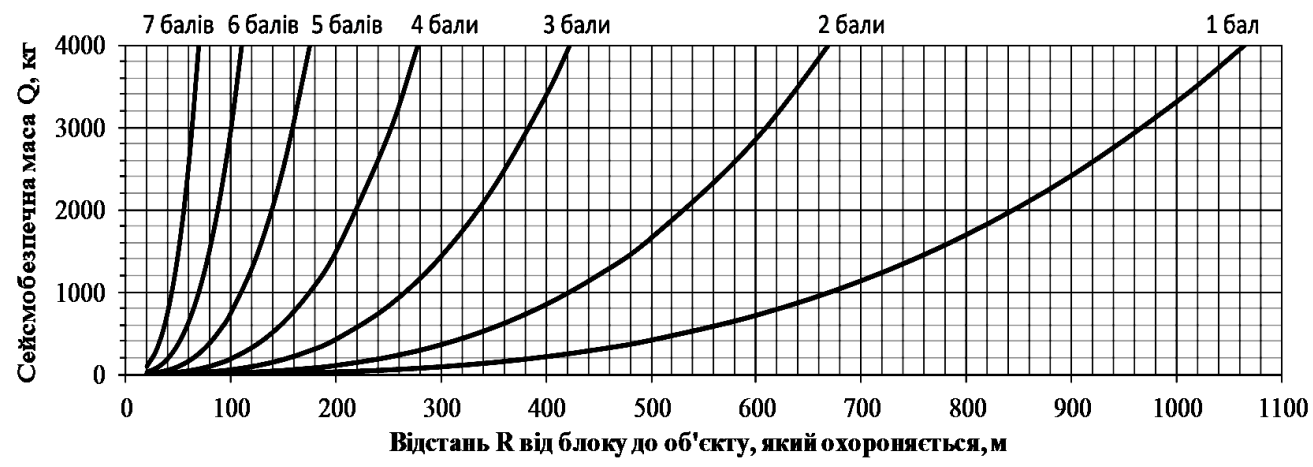

Рис. 2. Залежності сейсмобезпечної маси ВР від відстані до об'єкту, що охороняється (для системи ініціювання «ДШ»)

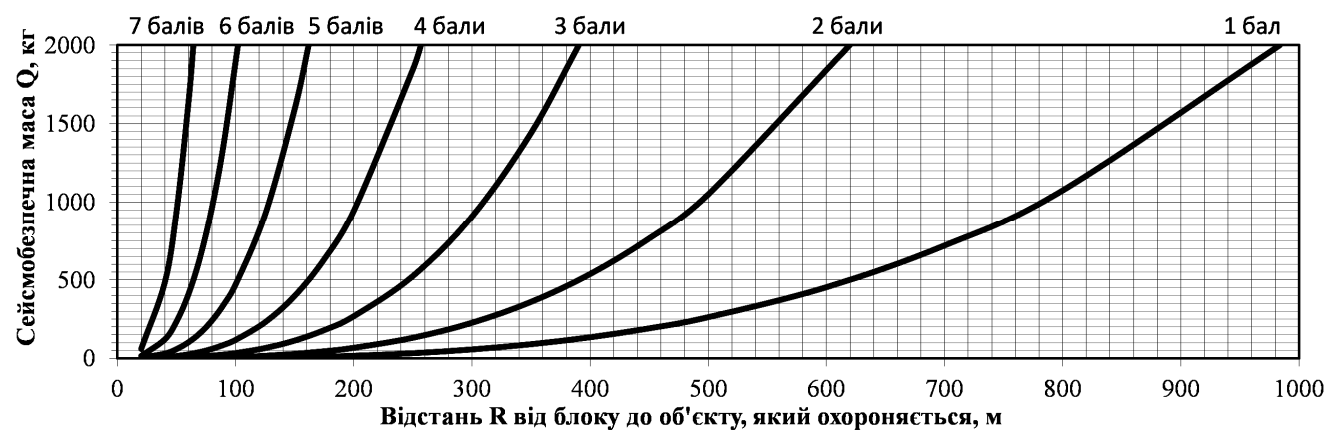

Рис. 3. Залежності сейсмобезпечної маси ВР від відстані до об'єкта, що охороняється (для системи ініціювання «Прима-Ера», «Нонель») 
Висновки. Застосований в даній роботі комплексний принцип дослідження та системний синтез отриманих результатів дозволяє обґрунтувати концептуально цілісну логіку модернізації гірничозбагачувальних комбінатів, а також послідовність розвитку суміжних кар'єрів й операційний зміст пропонованої технології за умов просторового їх об'єднання.

На переконання авторів, практичне застосування результатів дослідження щодо проектно-планувальних робіт значно підвищить адекватність їх рішень.

1. Вілкул Ю. Г., Азарян А. А., Колосов В. А., Караманиць Ф. І. Сучасний стан залізорудної галузі, прогноз розвитку та пропозиції. Качество минерального сырья : сб. науч. трудов. Кривой Рог : ГВУЗ «КНУ». 2017. С. 9-24. 2. Вилкул Ю. Г., Азарян А. А., Азарян В. А., Трачук А. А. Проблемы переработки минерального сырья техногенных месторождений Украины. Горная промышленность: научно-технический журнал. Москва, 2011. С. 13-15. 3. Бизов В. Ф., Федоренко П. Й. Вибухові роботи. Кривий Ріг : Мінерал, 2001. 230 с. 4. Бротанек И., Вода Й. Контурное взрывание в горном деле и строительстве. М. : Недра, 1983. 144 с. 5. Skachkov A. A., Zhukov S. A., Titov D. A. Symmetric blasting of rocks in conditions of open pit with narrow working fields. International Scientific and Technical Internet Conference "Innovative Development of Resource-Saving Technologies of Mineral Mining and Processing". Book of Abstracts. ISBN 978-973-741-616-2. Petroșani, Romania: UNIVERSITAS Publishing, 221 р. 2018. P. 61-64. 6. Совершенствование технологии буровзрывных работ на предельном контуре карьеров / В. А. Фокин, Г. Е. Тарасов, М. Б. Тогунов, А. А. Данилкин, Ю. А. Шитов. Апатиты : Изд-во Кольского научного центра РАН. 2008. 224 с. 7. Выбор оптимального режима совместной отработки перемычки между карьером № 3 ОАО «АрселорМиттал Кривой Рог» и карьером ОАО ЮГОК с использованием метода «Крутые слои». Проект 02-30-РП-ОПЗ. Харків : «Південгіпроруда», 2010. 94 с. 8. Спосіб виконання буро-вибухових робіт : пат. України : UA № 103516, С2 МПК (2013.10), F42 Д 3/04. Дата видачі 25.10.2013 р. Бюл. № 20. 9. ДСТУ-П4704:2006. Правила проведення гірничих вибухів. Норми безпечності сейсмічних коливань ґрунту. К. : Держспоживстандарт України, 2007. 10. Оника С. Г., Гаврик В. А. Определение параметров взрывных работ и расстояний, безопасных по действию сейсмических и ударных воздушных волн. Кривой Рог : НИГРИ, 1995. 26 с.

\section{REFERENCES:}

1. Vilkul Yu. H., Azarian A. A., Kolosov V. A., Karamanyts F. I. Suchasnyi stan zalizorudnoi haluzi, prohnoz rozvytku ta propozytsii. Kachestvo mineralnoho syria : sb. nauch. trudov. Krivoi Roh : HVUZ «KNU». 2017. S. 9-24. 2. Vilkul Yu. H., 
Azarian A. A., Azarian V. A., Trachuk A. A. Problemy pererabotki mineralnoho syria tekhnohennykh mestorozhdenii Ukrainy. Hornaia promyshlennost : nauchno-tekhnicheskii zhurnal. Moskva, 2011. S. 13-15. 3. Byzov V. F., Fedorenko P. Y. Vybukhovi roboty. Kryvyi Rih : Mineral, 2001. 230 s. 4. Brotanek I., Voda Y. Konturnoe vzryvanie $v$ hornom dele i stroitelstve. M. : Nedra, 1983. 144 s. 5. Skachkov A. A., Zhukov S. A., Titov D. A. Symmetric blasting of rocks in conditions of open pit with narrow working fields. International Scientific and Technical Internet Conference "Innovative Development of Resource-Saving Technologies of Mineral Mining and Processing". Book of Abstracts. ISBN 978-973-741-616-2. Petroșani, Romania: UNIVERSITAS Publishing, 221 p. 2018. R. 61-64. 6. Sovershenstvovanie tekhnolohii burovzryvnykh rabot na predelnom konture karerov / V. A. Fokyn, H. E. Tarasov, M. B. Tohynov, A. A. Danilkin, Yu. A. Shitov. Apatity : Izd-vo Kolskoho nauchnoho tsentra RAN. 2008. 224 s. 7. Vybor optimalnoho rezhima sovmestnoi otrabotki peremychki mezhdu karerom № 3 OAO «ArselorMittal Krivoi Roh» i karerom OAO YuHOK s ispolzovaniem metoda «Krutye sloi». Proekt 02-30-RP-OPZ. Kharkiv : «Pivdenhiproruda», 2010. 94 s. 8. Sposib vykonannia burovybukhovykh robit : pat. Ukrainy : UA № 103516, S2 MPK (2013.10), F42 D 3/04. Data vydachi 25.10.2013 r. Biul. № 20. 9. DSTU-P4704:2006. Pravyla provedennia hirnychykh vybukhiv. Normy bezpechnosti seismichnykh kolyvan gruntu. K. : Derzhspozhyvstandart Ukrainy, 2007. 10. Onika S. H., Havrik V. A. Opredelenie parametrov vzryvnykh rabot i rasstoianii, bezopasnykh po deistviiu seismicheskikh i udarnykh vozdushnykh voln. Krivoi Roh : NIHRI, 1995. $26 \mathrm{~s}$.

Vilkul Yu. H., Doctor of Engineering, Professor (Academy of Mining Sciences of Ukraine, President of the Academy, Kryvyi Rih),

Skachkov A. A., Mining Engineer (Northern Mine and Concentrator Complex, CEO,), Zhukov S. O., Doctor of Engineering, Professor (Kryvyi Rih National University)

\section{ORGANIZATIONAL AND TECHNOLOGICAL PRIORITIES OF SOLVING ENVIRONMENTAL AND INDUSTRIAL PROBLEMS OF KRYVBAS}

The purpose of the above is to determine current state and trends in mining industry of Ukraine; the environmental conditions of Kryvbas, and technological possibilities of reducing seismic effects of mass explosions in open pit. The methods of research are in the technical and economic analysis of Ukrainian mining industry, and as theoretical substantiation of technological solutions that reduce negative impact of opencast mining on the environment. 
Findings. The state and evolution trends of mining industry of Ukraine over the past ten years, as well as impact of mining enterprises on environment of the Kryvbas, are analyzed. It was determined that the most environmentally aggressive factor among technological processes is the explosive destruction of rocks. An analysis of the development of open pits № 3 of «ArcelorMittal Kryviy Rih» and «SouthMPC» indicates their spatial connection in the coming years. The immediate elimination of rocky whole between open pits is complicated both spatially and technologically, especially due to seismic constraints, but the solutions and measures developed by authors simplify and secure this stage as much as possible. Conclusions. Adaptation of the author's analytical substantiation of technology of rocks destruction to specific conditions of elimination the rock mass, which divides the neighboring open pits, is really promising.

The originality of the research lies in considering adjacent mines as a single complex dynamic system. Also, has adaptation of author's analytical substantiation for technology of rock-blasting destruction to specific conditions of elimination of rock mass separating adjacent open-cast.

Practical implications lies in fact that the results of research is determined by the high level of suitability for their use in design of the mining operations of the open pits «ArcelorMittal KR» and «SouthMPC».

Keywords: mining industry, open pit, explosive destruction.

Вилкул Ю. Г., д.т.н., профессор (Академия горных наук Украины, президент Академии, г. Кривой Рог), Скачков А. А., горный инженер (Северный горно-обогатительный комбинат, генеральный директор, г. Кривой Рог), Жуков С. А., д.т.н., профессор (ГВУЗ «Криворожский национальный университет», г. Кривой Рог)

ОРГАНИЗАЦИОННО-ТЕХНОЛОГИЧЕСКИЕ ПРИОРИТЕТЫ РЕШЕНИЯ ЭКОЛОГИЧЕСКИХ И ПРОМЫШЛЕННЫХ ПРОБЛЕМ КРИВБАССА

Цель исследования - определить современное состояние и тенденции в горной отрасли Украины; экологические условия Кривбасса и технологические возможности уменьшения сейсмических последствий массовых взрывов в карьерах. Методы исследования заключаются в технико-экономическом анализе горнодобывающей промышленности Украины, и в теоретическом обос- 
новании технологических решений, уменьшающих негативное влияние открытых разработок на окружающую среду.

Исследовано состояние и эволюционные тенденции горнодобывающей промышленности Украины за последние десять лет, а также влияние горнодобывающих предприятий на окружающую среду Кривбасса. Определено, что наиболее экологически агрессивным фактором среди технологических процессов является взрывное разрушение горных пород. Анализ разработки карьеров №3 «АрселорМиттал Кривой Рог» и «ЮГОК» свидетельствует об их пространственном слиянии в ближайшие годы. Непосредственная ликвидация скального целика между карьерами осложняется, как пространственно, так и технологически, особенно через сейсмические ограничения, но разработанные авторами решения и меры максимально упрощают и делают безопасной эту стадию.

Выводы. Адаптация авторского аналитического обоснования технологии разрушения горных пород к специфическим условиям ликвидации горного массива, который разделяет соседние карьеры, является реально перспективной.

Научная новизна исследования заключается в рассмотрении смежных карьеров как единой сложной динамической системы. Кроме того, - в адаптации авторского аналитического обоснования технологии взрывного разрушения пород к конкретным условиям ликвидации массива, разделяющей соседние карьеры.

Практическое значение состоит в том, что результаты исследований определяются высоким уровнем пригодности для их использования при проектировании горных работ карьеров «АрселорМиттал Кривой Рог» и «ЮГОК». Ключевые слова: горная промышленность, открытая разработка, взрывное разрушение. 